\title{
STUDY ON PERFORMANCE OF MANUFACTURED SAND AS FINE AGGREGATES IN HIGH STRENGTH CONCRETE CONSTRUCTIONS
}

\author{
S.S.Saravanan ${ }^{\# 1}$, Dr.P.Jagadeesh ${ }^{2}$ \\ ${ }^{\# 1}$ Research scholar, School of Civil \& Chemical Engineering, VIT University, India \\ 1ssaravanan513@gmail.com \\ ${ }^{2}$ Professor, School of Civil \& Chemical Engineering, VIT University, India \\ ${ }^{2}$ p.jagadeesh@vit.ac.in
}

\begin{abstract}
Paper presents the viability of manufactured sand as fine aggregates in high strength concrete (M60 Grade) construction. Due to rapid growth in industrial and infrastructural developments, necessitates huge demand of concrete for infrastructure development worldwide and extreme scarcity of natural sand availability. Investigation carried out by varying $0 \%$ to $100 \%$ replacement of natural sand using manufactured sand in high strength concrete mix with and without super plasticizer as an admixture. Current investigation revealed that M 60 Grade concrete using complete manufactured sand with super plasticizer yielded an excesses strength of $11.56 \%, 11.66 \%$ and14.85\% compared to conventional concrete for 7 days, 14 days and 28 days respectively with increase in slump. And an increase in compressive strength of $16.19 \%, 10.97 \%$ and $12.46 \%$ compared to conventional concrete without using admixture and a reduction of slump is noticed. Investigation reveals that, $100 \%$ replacement of manufactured sand exceeds the target strength, but $70 \%$ replacement performs better in workability and strength aspects.
\end{abstract}

Keyword - High strength concrete, Manufactured sand, Workability, Mechanical properties

\section{INTRODUCTION}

The rapid improvement in urbanization and industrialization all over the world made a huge demand on natural sand and it become as a scarce material, which is one of the prime constituent in cement concrete. Mining of sand posses the environmental problem and hence the government restricts the sand mining results scarcity of sand and increases the cost of sand. Hence availability of natural sand for concrete preparation also limited. Many authors done investigation on concrete by replacing sand by alternative materials such as, local materials, used sand, ceramic fines, bottom ash etc.([1],[3],[4],[6], [15]). Availability of above materials in large quantity is restricted to few areas and not in all places. But, manufactured sand/artificial sand can be made available everywhere due to availability of plenty of crushed stones. Due to depletion of natural sand, the easiest and cheapest way of getting the substitute for natural sand is by crushing the natural granite stones with vertical shaft impact crushers to get the artificial sand of desired size, shape and grades which would be free from all impurities such as clay and other soil particles. Manufactured sand used in the current investigation is made of crushing rock boulders in vertical shaft impact crushers. Few authors carried out studies on the compressive strength studies of concrete made of manufactured sand(M-sand)/artificial sand in varying proportions were higher than those of conventional concrete by using natural sand as fine aggregate ([2], [5], [7]-[14],[16]). However, it was found that workability of the concrete mixes decreased with an increase in percentage of M-sand as fine aggregate. It reveals that higher water requirement for concrete when M-sand replaced against natural sand. To maintain desired workability admixture is to be used.

For the purpose of experimentation concrete mix is designed for M60 grade concrete with natural sand and replaced with artificial sand by $0 \%$ to $100 \%$ with increment of $10 \%$. The super plasticizer (SP) is used in this present study is cera plast $300 \mathrm{RS}(\mathrm{G})$ as an admixture. A comparison of control mix concrete M-sand concrete to compressive strength, split tensile strength, and flexural strength of M60 concrete with concrete of various replacements of natural sand to manufactured sand is studied in this paper along with the workability of concrete. An attempt has been made to find optimal percentage replacement of fine aggregate with M-sand to get maximum strength. 


\section{A. Materials}

\section{EXPERIMENTAL PROGRAM}

Ordinary Portland cement of 53grade confirming to IS12269-1989, (Locally available brand Penna super) is used for this present study. The 28 days compressive strength of cement is $63.50 \mathrm{M} \mathrm{Pa}$ is used. The physical properties of cement are given in table 1 .

\section{TABLE-I .PHYSICAL PROPERTIES OF CEMENT}

\begin{tabular}{|l|l|}
\hline PROPERTY & VALUE \\
\hline Specific gravity & 3.15 \\
\hline Initial setting time & $33 \mathrm{~min}$. \\
\hline Final setting time & $385 \mathrm{~min}$. \\
\hline Fineness modulus & $1.68 \%$ \\
\hline Soundness & 5.50 \\
\hline Standard consistency & $28.20 \%$ \\
\hline
\end{tabular}

\section{B. Coarse Aggregates}

Crushed granite aggregates of (maximum size) 20mm size graded metal is used. Sieve analysis has been carried out by blending the aggregates of size $20 \mathrm{~mm}$ to $12.50 \mathrm{~mm}$ to get the good fineness modules. The coarse aggregate having specific gravity 2.70 , bulk density $1510 \mathrm{Kg} / \mathrm{m}^{3}$ and fineness modules 6.65 and Impact value of $12.50 \%$ were used. The physical properties of coarse aggregates are presented in Table .No 2

\section{Fine Aggregates}

\section{River sand}

Sand available in river Cauvery near Karur is used as fine aggregates for the current work, having the bulk density of $1460 \mathrm{~kg} / \mathrm{m} 3$, specific gravity 2.60 , and fineness modulus as 3.44 was used. The physical properties are presented in Table No 2.

\section{Manufactured sand (M-sand)}

Manufactured/Artificial sand is manufactured in vertical shaft impact crusher (VSI crusher at Salem) was collected from VSI crusher at Panamarathupatty, Salem. It is used as an alternate for river sand in replacement of fine aggregates. The bulk density of M-sand is $1556 \mathrm{~kg} / \mathrm{m}^{3}$, specific gravity and fineness modulus is found to be 2.45 and 3.54 respectively. The physical properties are presented in Table No-2.

TABLE-II. PHYSICAL PROPERTIES OF COARSE AGGREGATE AND FINE AGGREGATES

\begin{tabular}{|c|c|c|c|}
\hline \multirow[t]{2}{*}{ Property } & \multirow{2}{*}{$\begin{array}{l}\text { Coarse } \\
\text { Aggregate }\end{array}$} & \multicolumn{2}{|c|}{ Fine Aggregate } \\
\hline & & River Sand & M-sand \\
\hline Specific gravity & 2.70 & 2.60 & 2.45 \\
\hline Bulk density $\left(\mathrm{kg} / \mathrm{m}^{3}\right)$ & 1510 & 1460 & 1556 \\
\hline Water absorption (\%) & 0.45 & 1.00 & 0.85 \\
\hline Moisture content (\%) & 0.65 & 1.55 & 1.10 \\
\hline Aggregate impact value (\%) & 12.50 & - & - \\
\hline Fineness modules & 6.67 & 3.44 & 3.54 \\
\hline $\begin{array}{l}\text { Fineness particles } \\
\text { Less than } 150 \mathrm{~mm}(\%)\end{array}$ & - & 4.14 & 7.60 \\
\hline Sieve analysis & & Zone II & Zone II \\
\hline
\end{tabular}




\section{Super Plasticizer}

Cera plast $300 \mathrm{RS}(\mathrm{G})$ confirming to IS 9103 (1999) was used as super plasticizer. It is used to improve the workability properties.

\section{E. Mix proportion and casting of specimen}

Concrete mix was designed as per IS 10262 to achieve a grade of M60. The designed and adopted mix proportion was shown in Table 3. Eleven different mix proportions were casted with $0 \%, 10 \%, 20 \%, 30 \%, 40 \%$, $50 \%, 60 \%, 70 \%, 80 \%, 90 \%$ and $100 \%$ with partial replacement of natural with M-sand prepared with water binder ratio of 0.32 . In addition to that super plasticizer is also added to the mix to improve the workability of $1.2 \%$ dosage is identified as the optimum from marsh cone test. Similarly, a set of mixes are casted without super plasticizer. Concrete ingredients are mixed with a laboratory type concrete mixer machine. After mixing for four to five minutes the concrete was manually placed in the individual moulds and then all the specimens were well compacted using table vibrator roughly about 30 seconds. Casted specimens were demoulded after 24 hours and placed in curing up to 28 days. Table.3 shows the mix proportion details of present investigation.

TABLE-III . MIX PROPORTIONS

\begin{tabular}{|c|c|c|c|c|c|c|c|c|}
\hline \multirow{2}{*}{$\begin{array}{c}\text { Mix } \\
\text { Designation }\end{array}$} & \multirow{2}{*}{$\begin{array}{l}\text { M-Sand } \\
\text { (\%) }\end{array}$} & \multirow{2}{*}{$\begin{array}{l}\text { Water/ } \\
\text { Cement }\end{array}$} & \multirow[t]{2}{*}{ SP } & \multicolumn{5}{|c|}{ Quantities (kg/m³) } \\
\hline & & & & Water & Cement & $\begin{array}{l}\text { River } \\
\text { Sand }\end{array}$ & $\begin{array}{c}\text { M- } \\
\text { Sand }\end{array}$ & $\begin{array}{c}\text { Course } \\
\text { Aggregate }\end{array}$ \\
\hline M1 & 0 & 0.32 & $1.2 \%$ & 144 & 450 & 627 & 0 & 1208 \\
\hline M2 & 10 & 0.32 & $1.2 \%$ & 144 & 450 & 564.3 & 62.7 & 1208 \\
\hline M3 & 20 & 0.32 & $1.2 \%$ & 144 & 450 & 501.6 & 125.4 & 1208 \\
\hline M4 & 30 & 0.32 & $1.2 \%$ & 144 & 450 & 438.9 & 188.1 & 1208 \\
\hline M5 & 40 & 0.32 & $1.2 \%$ & 144 & 450 & 376.2 & 250.8 & 1208 \\
\hline M6 & 50 & 0.32 & $1.2 \%$ & 144 & 450 & 313.5 & 313.5 & 1208 \\
\hline M7 & 60 & 0.32 & $1.2 \%$ & 144 & 450 & 250.8 & 376.2 & 1208 \\
\hline M8 & 70 & 0.32 & $1.2 \%$ & 144 & 450 & 188.1 & 438.9 & 1208 \\
\hline M9 & 80 & 0.32 & $1.2 \%$ & 144 & 450 & 125.4 & 501.6 & 1208 \\
\hline M10 & 90 & 0.32 & $1.2 \%$ & 144 & 450 & 62.7 & 564.3 & 1208 \\
\hline M11 & 100 & 0.32 & $1.2 \%$ & 144 & 450 & 0 & 627 & 1208 \\
\hline
\end{tabular}

Experimental work consists of three cubes of sizes $150 \mathrm{~mm}$ x $150 \mathrm{~mm}$ x $150 \mathrm{~mm}$ were casted from each mix of concrete to evaluate compressive strength of concrete. For split tensile test $150 \mathrm{~mm}$ diameter, $300 \mathrm{~mm}$ height cylinder and $100 \mathrm{~mm}$ x 100mm x $500 \mathrm{~mm}$ prism were casted.

Three concrete samples were tested to evaluate the average value of all concrete mixes after 7, 14 and 28 days curing in water as per IS-9013 for compressive strength. Split tensile strength was conducted on concrete cylinder after 7, 14 and 28 days curing as per IS-5816 and likewise for modulus of rupture was carried on prism after 7, 14 and 28 days curing as per IS-9399.

\section{RESULT AND DISCUSSION}

The workability of concrete with and without plasticizer is tested by slump test for W/C ratio of 0.32 (as per BIS1199-1959) and 0.35 for different mix proportions of natural sand and M-sand. The results are tabulated in Table 4. The values show that, increase in percentage of M-sand in concrete causes reduction in the slump values. Also reveals that, concrete with plasticizer considerably improved the slump values compared to concrete without plasticizer. Concrete after properly curried for 7 days, 14 days and 28 days are taken from the curing tank and exposed for few hours for natural conditions and then tested in 2 tonne capacity concrete compressive testing machine. The compressive strength of various mixes of M60 grade without and with plasticizer are shown in Figure-1and 2.The split tensile strength results are presented in Figure-3and 4 and flexural strength values are presented in Figure-5and 6 for with and without super plasticizer respectively. 
TABLE: 4 WORKABILITY OF CONCRETE FOR DIFFERENT MIXES (SLUMP)

\begin{tabular}{|c|c|c|c|}
\hline \multirow{2}{*}{ S. No. } & \multirow{2}{*}{ Mix } & \multicolumn{2}{|c|}{ Slump (mm) } \\
\cline { 3 - 4 } & Proportion & Without SP & With SP \\
\hline 1 & M1 & 55 & 62 \\
\hline 2 & M2 & 52 & 65 \\
\hline 3 & M3 & 50 & 65 \\
\hline 4 & M4 & 49 & 68 \\
\hline 5 & M5 & 49 & 68 \\
\hline 6 & M6 & 45 & 75 \\
\hline 7 & M7 & 40 & 78 \\
\hline 8 & M8 & 36 & 80 \\
\hline 9 & M9 & 35 & 82 \\
\hline 10 & M10 & 34 & 85 \\
\hline 11 & M11 & 34 & 85 \\
\hline
\end{tabular}

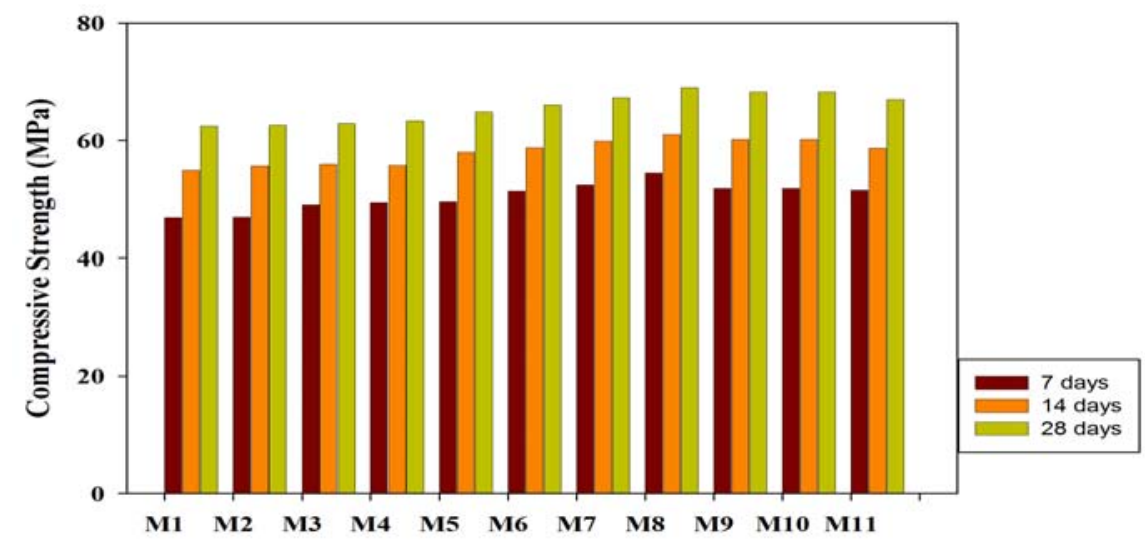

Fig. 1. Compressive strength of concrete without SP after 7, 14 \& 28 days curing

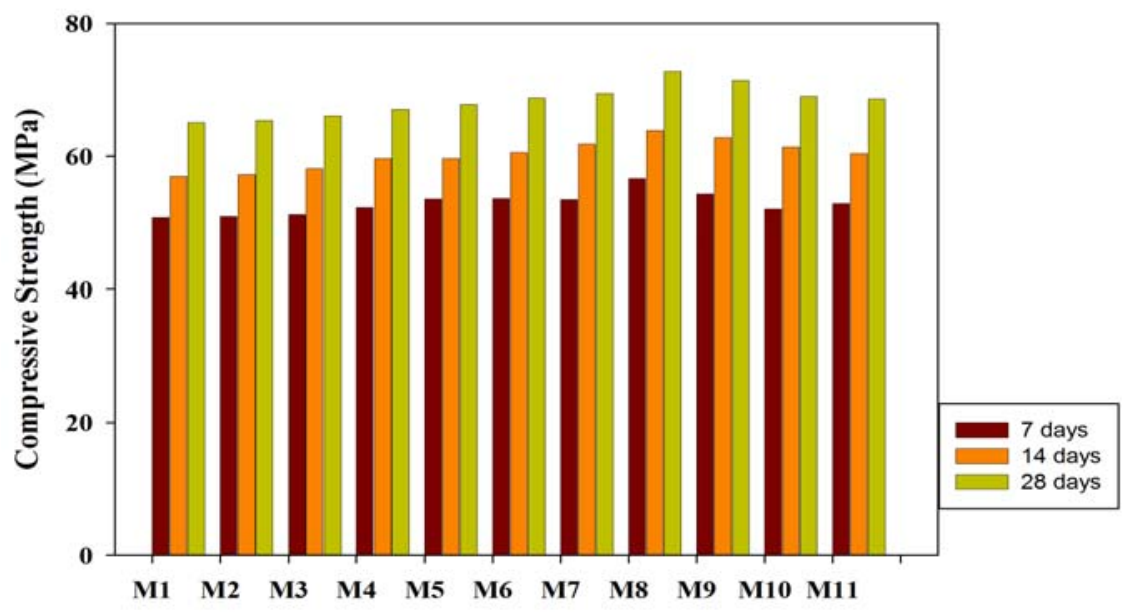

Fig. 2. Compressive strength of concrete with SP 7, 14 \& 28 days curing 


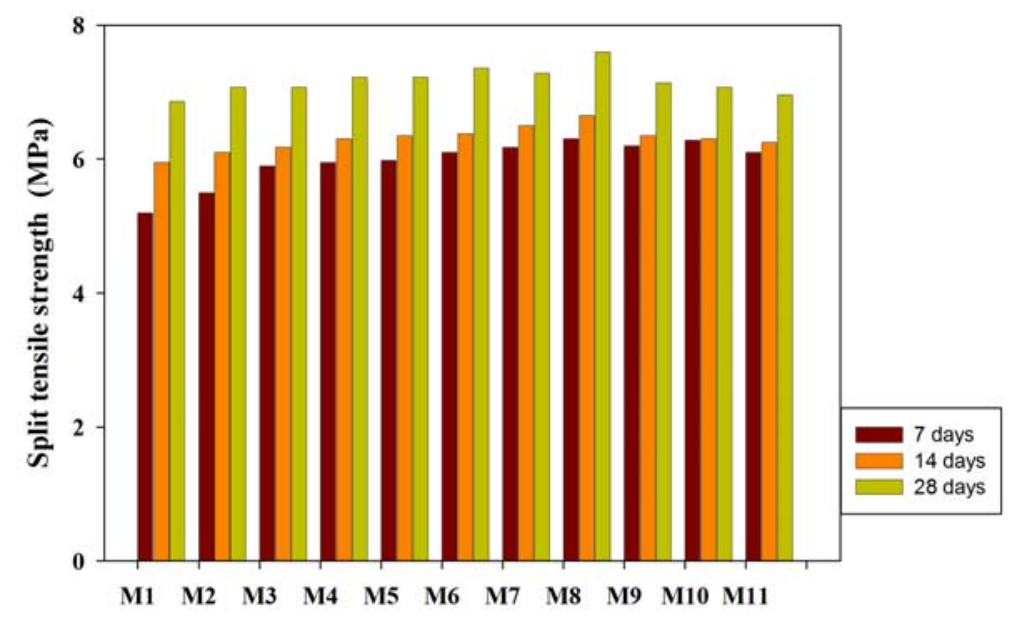

Fig. 3. Split tensile Strength of concrete without SP 7, 14 \& 28 days curing

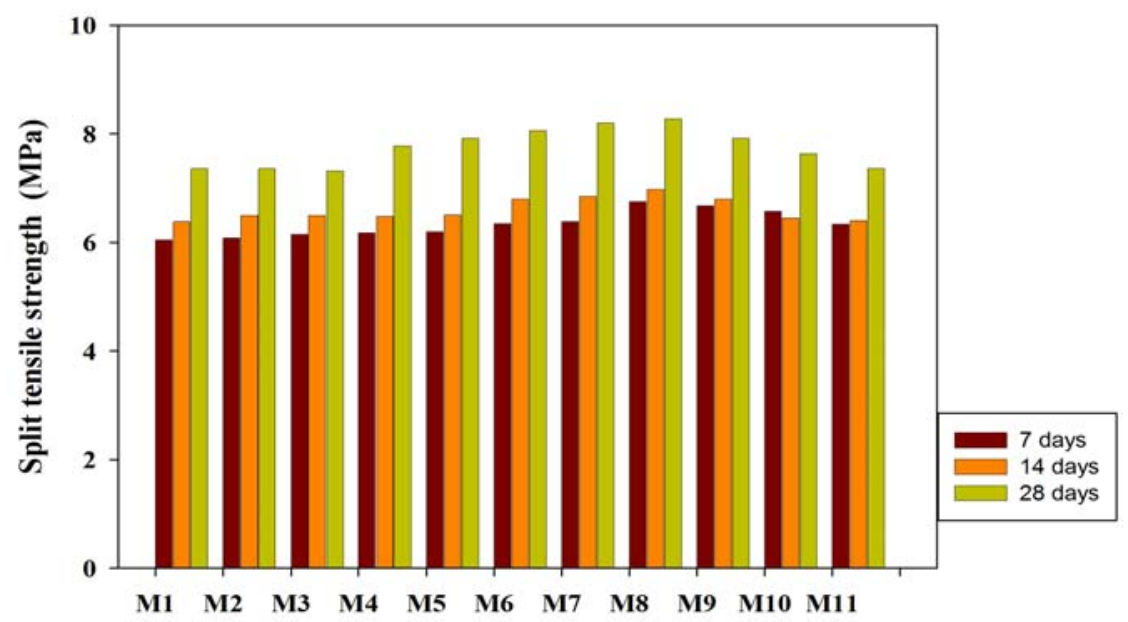

Fig. 4. Split tensile Strength of concrete with SP 7, 14 \& 28 days curing

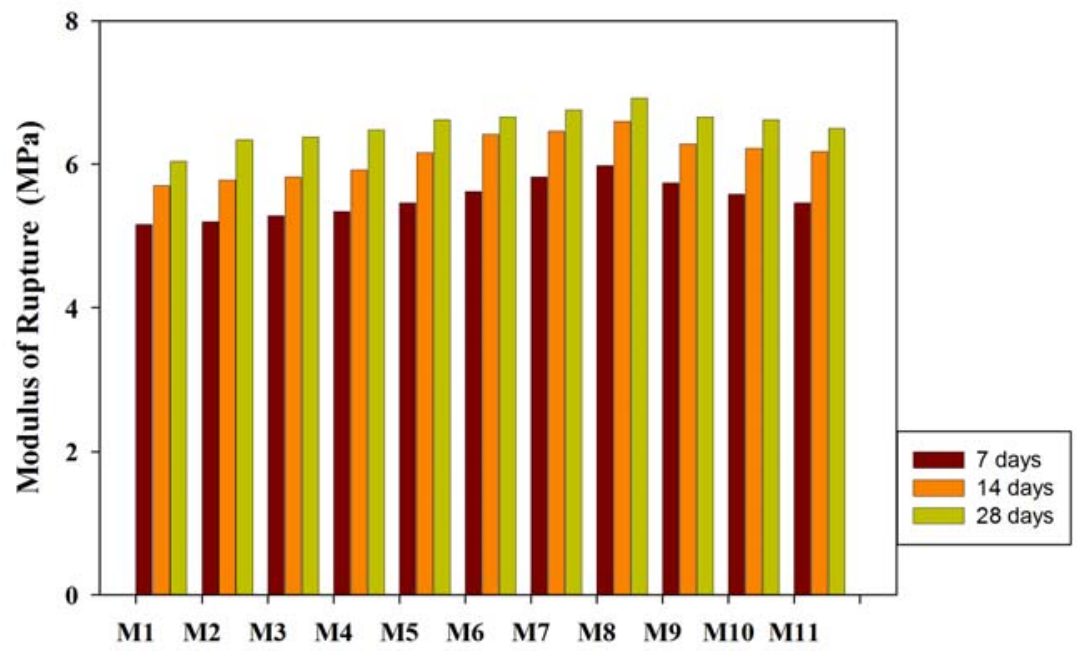

Fig. 5 Modulus of rupture of concrete without SP 7, 14 \& 28 days curing 


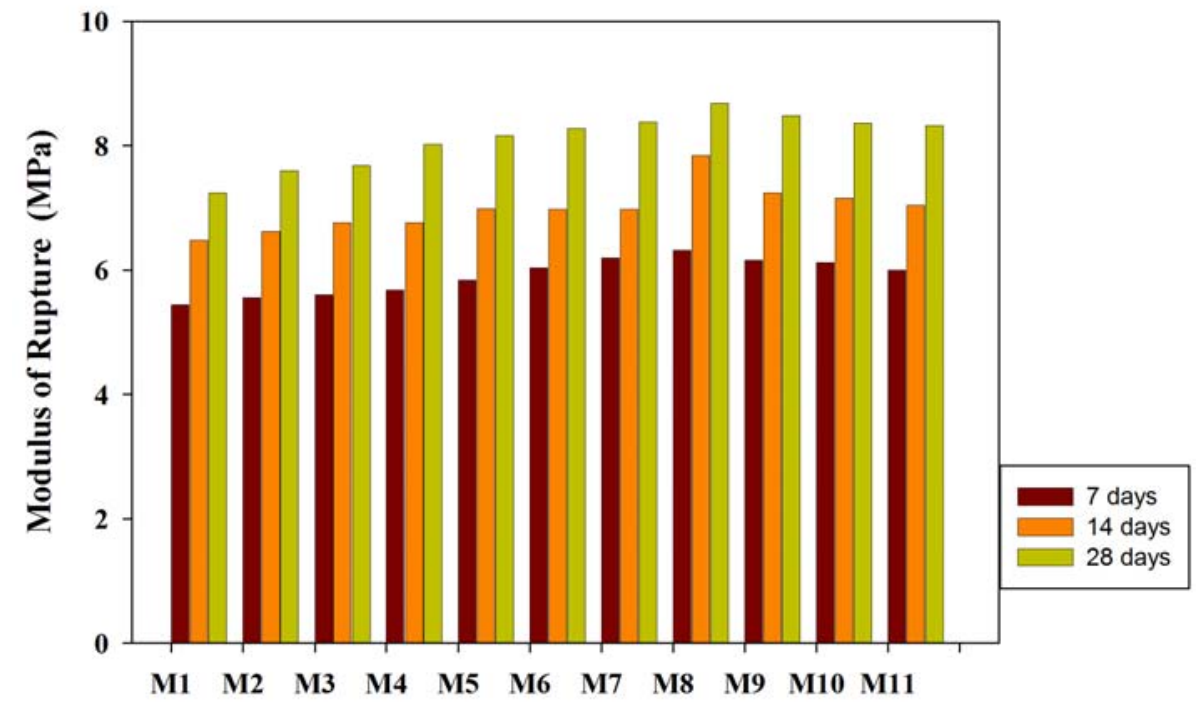

Fig. 6 Modulus of rupture of concrete with SP 7, 14 \& 28 days curing

\section{CONCLUSION}

The following are the conclusions drawn from the current investigation.

$>$ For M60 concrete mix using 100\% natural river sand and without admixture yielded a 28 days compressive strength of 62.44MPa. However, M60 concrete with $70 \%$ replacement of natural sand by Msand yield compressive strength of $70.22 \mathrm{MPa}$, which is $12.46 \%$ higher .The compressive strength of concrete with admixture yielded a 28 days compressive strength of $65.08 \mathrm{MPa}$ and of at $70 \%$ replacement of natural sand by M-sand yield compressive strength of $74.44 \mathrm{MPa}$ which is $14.85 \%$ higher than the conventional concrete.The compressive strength of all mixes increased with age from 7 days to 28 days. Current investigation revealed that compressive strength decreases at 28 days for concrete without SP and beyond $70 \%$ replacement of natural sand by M-sand. On the other hand, compressive strength decreases at 28 days for concrete with admixture for beyond $70 \%$ replacement of natural sand by M-sand. Hence for achieving maximum strength of M60 concrete, the optimum replacement of natural sand up to $70 \%$ permissible with admixture and beyond $70 \%$ replacements of natural sand also yields the better strength than the natural sand

$>$ The split tensile strength of concrete with an admixture at 7 days, 14 days and 28 days are $11.57 \%$, $12.94 \%$ and $14.05 \%$ respectively more than the conventional concrete. And for concrete without admixture at 7 days,14 days and 28 days are more by $19.23 \% 11.76 \%$ and $12.46 \%$ respectively than the conventional concrete.

$>$ The flexural strength of concrete with an admixture are more by $16.18 \%, 20.99 \%$ and $19.89 \%$ respectively and without admixture are more by $15.89 \%, 15.79 \%$ and $14.56 \%$ respectively than the controlled concrete at 7 days, 14 days and 28 days.

$>$ Concrete mix becomes hard and lesser workability with increase in percentage of manufactured sand. Hence use of admixture increase the workability of M-sand replaced concrete mix. The optimum dosage of admixture is calculated using Marsh cone test.

> The M60 concrete prepared using the M-sand yielded the satisfactory results in terms of compressive strength, split tensile strength, flexural strength and workability. Hence use M-sand for high concrete is recommended with correct gradation as per standards.

\section{REFERENCES}

[1] Srinivas Allena and CraigM.Newton, "Ultra High strength concrete mixtures using local material”, Journal of Civil Engineering \& Architecture, Vol. 5, pp.322-330, 2011.

[2] VeeraReddy M, "Investigation on stone dust and ceramic scrap as aggregate replacement in concrete", Internation Journal of Civil and Structural Engineering, Vol.1, No3, pp.661-666, 2010.

[3] Rafat Siddique, Geerif de scfutter, "Albert Noumoue. Effect of used sand on the Mechanical properties of concrete”, Vol.23, pp.976800, 2009.

[4] Richardson, AE, Coventry K., Graham. S.Coventry, “Concrete Manufactured with ungraded recycled aggregates” Structural Survey. Vol. 27, No.1, pp.62-70, 2009.

[5] Ilangovan, Mahendran R., K.Nagamani K., "Strength and durability properties of concrete containing quarry rock dust as fine aggregates”, ARPN Journal of Engineering and applied Science. Vol.3, No.5, pp.20-26, 2008. 
[6] Diwakar, Manjunath Y.S., Aswath M.U., "Experimental Investigation on behaviour of concrete with use of ceramic fines”, Internation Journal of Advanced Engineering Research and studies, Vol.1, No.4, pp.84-87, 2012.

[7] Ilangovan.R., K.Nagamani K, “Application of Quarry rock dust as fine aggregate in concrete construction”, National Journal on construction Management NICMR, PUNE, December,pp.5-13, 2006.

[8] Mahzuh H.M.A., AhmedA.A.M., Yusur M.A., "Use of stone powder in concrete and moter as an alternative of sand" African Journal of Environmental Science and Technology, Vol. 5, No.5, pp. 381-388, 2010.

[9] ShyamPrakash V, "Ready mixed concrete using manufactured sand as fine aggregate", $32^{\text {nd }}$ Conference on our world in concrete and structures, Singapore 28-29 August 2007.

[10] Priyanka A., Jadhav,DilipK.Kullkarni, "Effect of replacement of natural sand by manufactured sand on the properties of mortar", International journal of civil and structural Engineering. Vol.3, pp.621-628, 2013.

[11] Er.LakhanNagpal, Arvind Dewaganet, "Evaluation of strength characteristics of concrete using crushed stone dust as fine aggregates", International journal of innovative Technology and Exploring Engineering,, Vol. 2, No.6, pp.102-104, 2013.

[12] Sahu A.K. SunilKumar and Sachan A.K.,"Quarry Stone waste as fine aggregate for concrete”. The Indian Concrete Journal, pp.845$848,2003$.

[13] Manguriu.G.N.Karuguet,“Partial Replacement of natural River sand with crushed Rock sand in concrete production,” Global Engineer Technologist Review, Vol.5 pp.7-14, 2013.

[14] Manasseh Joel, "Use of crushed granite fine as Replacement to river sand in concrete production,” Leonardo Electronic Journal of Practices and Technologies, Vol.17, pp.85-96,2010.

[15] Soman .K.Divyasasi, "Strength Properties of concrete with partial replacement of sand by bottom ash", International Journal of Innovative Research in advanced Engineering, Vol. 7, pp.223-227, 2014.

[16] Saravanan.S.S.,P.Jagadesh "Evaluation of M30 grade concrete with manufactured sand,” National Conference on modern construction materials and Technology, Sponsored by BRNS, Chennai, 2014.

[17] IS 383, "Specification for coarse and fine aggregate from natural sources for concrete”,Bureau of Indian Standards,New Delhi,1970.

[18] IS 12269, "Specifications for 53 grade ordinary Portland cement”, Bureau of Indian Standards, New Delhi, 1989.

[19] IS 10262, "Recommended Guidelines for concrete mix Design”, Bureau of Indian Standards, New Delhi,2009.

[20] IS 1199, "Method of test for slump of concrete”, Bureau of Indian Standards, New Delhi, 1959.

[21] IS 516, "Method of test for strength of concrete", Bureau of Indian Standards, New Delhi,1959.

[22] IS 9103, “Concrete Admixtures - Specification”, Bureau of Indian Standards, New Delhi, 1999.

[23] IS 9013, "Method of making, curing and determining compressive strength of accelerated-cured concrete", Bureau of Indian Standards, New Delhi, 2008.

[24] IS 5816, "Splitting tensile strength of concrete - method of test”, Bureau of Indian Standards, New Delhi, 2004

[25] IS 9399, "Specification for apparatus for flexural testing of concrete”, Bureau of Indian Standards, New Delhi,2004.

\section{AUTHOR'S PROFILE}

Mr. S.S.Saravanan, Completed ME in College of Engineering, Guindy, ANNA University, Chennai 25,currently a research scholar in the School of Civil and Chemical Engineering, VIT University, Vellore 632014, India. His area of interest includes Concrete Technology pertaining to Highways. His mail id is ssaravanan513@gmail.com, contact phone no 09443011975

Dr. P. Jagadeesh currently working as Professor in the School of Civil and Chemical Engineering, VIT University, Vellore - 632014, India. He did his Ph.D in Indian Institute of Technology Madras, Department of Ocean Engineering, Chennai, India and Post Doc in University of Western Australia, Perth. His research interest includes Hydrodynamics, Concrete Technology and Construction Management. 